Southern Methodist University

SMU Scholar

Faculty Journal Articles and Book Chapters

Faculty Scholarship

2021

\title{
COVID-19 and Law Teaching: Guidance on Developing an Asynchronous Online Course for Law Students
}

Yvonne Dutton

Seema Mohapatra

Southern Methodist University, Dedman School of Law

\section{Recommended Citation}

Yvonne M. Dutton \& Seema Mohapatra, COVID-19 and Law Teaching: Guidance on Developing an Asynchronous Online Course for Law Students, 65 St. Louis U. L.J. 471 (2021)

This document is brought to you for free and open access by the Faculty Scholarship at SMU Scholar. It has been accepted for inclusion in Faculty Journal Articles and Book Chapters by an authorized administrator of SMU Scholar. For more information, please visit http://digitalrepository.smu.edu. 


\title{
COVID-19 AND LAW TEACHING: GUIDANCE ON DEVELOPING AN ASYNCHRONOUS ONLINE COURSE FOR LAW STUDENTS
}

\author{
YVOฌNE M. DUTTON* AND SEEMA MOHAPATRA**
}

\begin{abstract}
Most law schools suspended their live classroom teaching in March 2020 due to the COVID-19 pandemic and quickly transitioned to online programming. Although professors can be commended for rapidly adapting to an emergency situation, some commentators have nevertheless suggested that the emergency online product delivered to students was substandard. Based on our own experiences in designing and delivering online courses, we caution against embracing a broad-reaching, negative conclusion about the efficacy of online education. Indeed, much of this emergency online programming would be more properly defined as "emergency remote teaching," as opposed to "online education." Online education requires professors to design their courses to be delivered at a distance, with the goal being to create a course driven by pedagogy using technological tools to inform and enhance the learning experience. COVID-19 may be with us for the foreseeable future, and law schools may choose to deliver more of their courses online as a result. This Article offers some guidance on how to develop and implement an effective asynchronous distance-learning course for law students.
\end{abstract}

* Professor of Law, Indiana University Robert H. McKinney School of Law.

** Murray Visiting Professor of Law, SMU Dedman School of Law. Thanks to Indiana University and the IU McKinney School of Law for supporting the development of online distance learning classes. We are grateful to Zach Carnagey, Anna Lynch, Julia Sanders, and the IUPUI Center for Teaching and Learning and eLearning Design \& Services, UITS for course design work and guidance in creating the courses mentioned in this Article. For research assistance, we thank Research Librarians, Benjamin Keele and Susan DeMaine. We would like to thank Margaret Ryznar, Max Huffman, and Nina Kohn for helpful comments. 


\section{INTRODUCTION}

Most colleges, universities, and law schools, including the authors' own institution, Indiana University Robert H. McKinney School of Law ("IU McKinney"), ${ }^{1}$ suspended their live classroom teaching in March 2020 due to the COVID-19 pandemic and quickly transitioned to online educational programming. ${ }^{2}$ The American Bar Association ("ABA") specifically granted permission for law schools to move online during the pandemic, citing to standards allowing deviation from ordinary governing rules during emergencies or disasters. ${ }^{3}$ For most institutions of higher education, this rapid move online meant scrambling quickly to educate professors on the basics of teaching remotely. ${ }^{4}$ When classes resumed, the new "online" world commenced. In many cases, that new world consisted of professors hosting classes on Zoom ${ }^{5}$ or a similar platform where the teacher and students met online by videoconference

1. Press Release, Indiana Univ., IU Extends Spring Break and Moves to Remote Teaching for the Remainder of the Spring 2020 Semester (Mar. 15, 2020), https://news.iu.edu/stories/2020 /03/iu/releases/15-extends-spring-break-remote-teaching-remainder-of-semester.html [https://per ma.cc/JYF5-MW36].

2. See, e.g., Andrew Smalley, Higher Education Responses to Coronavirus (COVID-19), NAT'L CONF. OF STATE LEGISLATURES (July 27, 2020), https://www.ncsl.org/research/education /higher-education-responses-to-coronavirus-covid-19.aspx [https://perma.cc/Q2G4-VL3T] (noting that by mid-March 2020 over 1,100 institutions in all fifty states had canceled in-person classes or shifted to online instruction); Digital Learning Pulse Survey: Immediate Priorities-A Snapshot of Higher Education's Response to the COVID-19 Pandemic, CENGAGE, https://blog.cengage.com /digital-learning-pulse-survey-immediate-priorities-a-snapshot-of-higher-eds-response-to-covid19 [https://perma.cc/AS8Y-VGC5] [hereinafter Digital Learning Pulse Survey] (noting that, as of mid-April 2020,90\% of responding administrators and faculty said instruction had moved online).

3. Managing Director's Guidance Memo, Emergencies and Disasters, AM. BAR ASs'N (Feb. 2020), https://www.americanbar.org/content/dam/aba/administrative/legal_education_and_admis sions_to_the_bar/20-feb-guidance-on-disasters-and-emergencies.pdf [https://perma.cc/RYE7-DX BL] [hereinafter Managing Director's Guidance Memo]. Standard 306 has been removed from the 2020-21 ABA Standards. See ABA STANDARDS AND Rules FOR APproval OF LAW SchOols 2020-21 (AM. BAR ASs'N 2020), https://www.americanbar.org/content/dam/aba/administrative /legal_education_and_admissions_to_the_bar/standards/2020-2021/2020-21-aba-standards-andrules-for-approval-of-law-schools.pdf [https://perma.cc/E7Y4-NFXV].

4. Digital Learning Pulse Survey, supra note 2 (survey indicates $97 \%$ of institutions had faculty with no experience teaching their courses online as they moved to online teaching in response to the virus); John Hechinger \& Janet Lorin, Coronavirus Forces $\$ 600$ Billion Higher Education Industry Online, BLOOMBERG (March 19, 2020), https://www.bloomberg.com/news /articles/2020-03-19/colleges-are-going-online-because-of-the-coronavirus [https://perma.cc/6T28 -UEVV] (stating that as classes went online in response to the virus, 70 percent of America's 1.5 million faculty members had no experience teaching virtually).

5. Zoom is a major vendor of video communications services to businesses and educational institutions. ZOOM FOR EDUCATION, https://zoom.us/education [https://perma.cc/23HS-VZNY]. 
during the previously-scheduled class time. ${ }^{6}$ In other cases, professors instead sent students PowerPoints, videos, or reading materials. ${ }^{7}$

Institutions of higher education and their professors can be commended for rapidly adapting to an emergency situation. ${ }^{8}$ Some commentators nevertheless suggested that the emergency online product delivered to students was substandard as compared to the live classes that predated the COVID-19 response. ${ }^{9}$ Some students went even further, bringing lawsuits against their institutions to request a tuition refund because of the alleged failure to provide an equivalent education. ${ }^{10}$ The takeaway lesson of this emergency online transition, according to some commentators, is that online education is no match in quality as compared to education delivered to students live in the classroom. ${ }^{11}$ However, what was delivered at most institutions with sometimes a week's notice, while laudable due to the quick transition, should not be used to judge online courses in general.

Based on our own experiences in designing and delivering online courses at IU McKinney-experiences we share in this Article-we caution against

6. Jon Marcus, Will the Coronavirus Forever Alter the College Experience?, N.Y. TIMES (April 23, 2020), https://www.nytimes.com/2020/04/23/education/learning/coronavirus-online-ed ucation-college.html [https://perma.cc/J5HP-DQ2G] (quoting a professor at Dartmouth's Tuck School of Business as stating that what we are seeing now is not "online education," but rather professors rushing to put everything they do on Zoom).

7. See Matt Krupnick, Forced off campus by coronavirus, students aren't won over by online education, PBS NEwSHOUR (March 19, 2020, 12:37 PM), https://www.pbs.org/newshour /education/forced-off-campus-by-coronavirus-students-arent-won-over-by-online-education [https://perma.cc/2WPP-Z4FN].

8. See Doug Lederman, Preparing for a Fall Without In-Person Classes, INSIDE HIGHER ED (Apr. 1, 2020), https://www.insidehighered.com/digital-learning/article/2020/04/01/preparing-qui etly-fall-semester-without-person-instruction [https://perma.cc/QG8G-RPWV] (suggesting that universities, teachers, staff, and students should be applauded for tackling the shift to remote learning in response to the virus).

9. Henry Kronk, Online J.D. Had to Emphasize Quality to Gain Accreditation. Now Educators Fear Negative Attitudes to Online Learning Will Mount After Pandemic Subsides., ELEARNING INSIDE (Apr. 27, 2020), https://news.elearninginside.com/online-j-d-programs-had-toemphasize-quality-to-gain-accreditation-now-educators-fear-negative-attitudes-to-online-learning -will-mount-after-the-pandemic-subsides/ [https://perma.cc/E9PX-WB6] (quoting Nina Kohn, a professor from Syracuse University College of Law as stating that "the overall reputation of online learning may suffer because the [pandemic] version of online learning most people will have experienced will have little resemblance to best practice.").

10. Students at 25 Colleges Sue for Refunds After Campuses Close Because of Coronovirus, NBC NEws (May 5, 2020), https://www.nbcnews.com/news/us-news/students-25-universitiessue-refunds-after-campuses-close-due-coronavirus-n1200746 [https://perma.cc/3RNR-CTCH] (explaining that students were alleging, among other things, that the emergency online classes were "poor substitutes for classroom learning.").

11. Marcus, supra note 6 (stating that 67 percent of the 14,000 college and graduate students surveyed in an April 2020 poll said they did not find their online classes as effective as their live classes). 
embracing a broad-reaching negative conclusion about the efficacy of online education. First, much of this emergency online programming would be more properly defined as "emergency remote teaching," 12 as opposed to "online education." 13 Delivering online education to students involves more than giving the same classroom lecture on Zoom. ${ }^{14}$ Some professors teaching online classes might properly conclude that live teaching via Zoom or other similar platforms is the best methodology for their course. Indeed, synchronous live classes may be well-suited for some smaller classes where the professor determines that employing the Socratic method or facilitating "live" discussions are necessary to master course learning objectives. ${ }^{15}$ Additionally, different teachers may conclude that they teach better in live modalities. On the other hand, some teachers may decide that course content may be better delivered using a host of different tools that are available to those teaching in the online environment. Online education requires professors to design their courses to be delivered at a distance, with the goal being to create a course driven by pedagogy using

12. See Charles Hodges et al., The Difference Between Emergency Remote Teaching and Online Learning, EDUCAUSEREVIEW (March 27, 2020), https://er.educause.edu/articles/2020/3/the -difference-between-emergency-remote-teaching-and-online-learning [https://perma.cc/MDN9SFKB] (stating that the primary objective of "emergency remote teaching" is "to provide temporary access to instruction and instructional supports in a manner that is quick to set up and is reliably available during an emergency or crisis.").

13. See, e.g., Lee Gardner, COVID-19 Has Forced Higher Ed to Pivot to Online Learning: Here are 7 Takeaways So Far, CHRON. HIGHER EDUC. (March 20, 2020), https://www.chronicle .com/article/covid-19-has-forced-higher-ed-to-pivot-to-online-learning-here-are-7-takeaways-sofar/ [https://perma.cc/Z6PU-HXEU] (quoting Susan Grajek of Educause, a non-profit advocating the use of technology in education, as stating that much of what we are seeing in response to the pandemic is more properly characterized as remote education, as opposed to online education); Laura Barker, Remote Teaching vs. Online Learning in Higher Education Today, GRANTHAM UNIV. (Apr. 15, 2020), https://www.grantham.edu/blog/remote-teaching-vs-online-learning-inhigher-education-today/ [https://perma.cc/2V9F-Y6JC] (stating that the pandemic-induced remote learning may not be similar at all to structured online courses); Lederman, supra note 8 (stating that "the kind of emergency remote learning that most campuses delivered on the fly during this spring's crisis may have been sufficient for the moment," but was not as good as what is available in a high-quality online program, nor as good as what most colleges deliver in person).

14. See, e.g., Karen Sloan, Law Schools Shift Classes Online Amid COVID-19, but Can They Do it Successfully?, LAw.COM (March 10, 2020, 4:10 PM), https://www.law.com/2020/03/10/lawschools-shift-classes-online-amid-covid-19-but-can-they-do-it-right/ [https://perma.cc/7KMM-M XGR] (explaining that one type of online class is the self-paced asynchronous class and that developing such a course "in a way that is high quality takes a real investment of time, energy, and rethinking how you break down what is normally a live experience into self-paced components"); Krupnick, supra note 7 (noting that in a well-planned online course, "professors use technology that allows group discussions, posting of materials, and other interactive features.").

15. See, e.g., Sloan, supra note 14 (noting that Zoom can be appropriately used in some classrooms, particularly if the teacher has a screen that allows him or her to see all student participants at the same time). 
technological tools to inform and enhance the learning experience. ${ }^{16}$ For many, this means offering asynchronous courses that allow students to move at their own pace, and that require students to continually complete assessments to demonstrate mastery of material and skills. ${ }^{17}$ These types of courses are "carefully designed to deliver a learning experience that does not depend on being face-to-face with the instructor."18

COVID-19 and its variants may be with us for some time, with the result being that online teaching and learning may also be with us for some time. ${ }^{19} \mathrm{At}$ least thirty-two law schools were entirely online for the fall 2020 semester or offered limited in person classes to small groups of students. ${ }^{20}$ Widespread online options were similarly available in Spring 2021 - a time when vaccines initially were scarce. ${ }^{21}$ Even in Summer 2021, and despite vaccines being widely available in the US, many colleges and universities stayed the course, offering plenty of online courses to their students. ${ }^{22}$ While many schools have indicated

16. Gardner, supra note 13 (quoting the President of Hampshire College as stating that "online instruction is a discipline backed by decades of learning science," and "a process that takes months, if not sometimes years, to do properly"); Hodges et al., supra note 12 ("What we know from research is that effective online learning results from careful instructional design and planning, using a systematic model for design and development.").

17. Marcus, supra note 6 (quoting experts in online education).

18. Barker, supra note 13; see also John A. Byrne, $P \& Q$ Survey: A Third Of Admits May Defer, While 43\% Want Tuition Lowered If Classes Are Online, POETS \& QUANTS (March 29, 2020), https://poetsandquants.com/2020/03/29/pq-survey-a-third-of-admits-may-defer-while-43want-tuition-lowered-if-classes-are-online/ [https:/perma.cc/VTL8-AAEH] (stating that when “the University of Michigan's Ross School of Business put its MBA program online last year, each professor spent anywhere between 100 to 200 hours rethinking their courses and putting them in a format that would maximize a course's learning objectives.").

19. See, e.g., Frank Bruni, Opinion, She Predicted the Coronavirus. What Does She Foresee Next?, N.Y. TIMES (May 2, 2020), https://www.nytimes.com/2020/05/02/opinion/Sunday/corona virus-prediction-laurie-garrett.html [https://perma.cc/5BKY-FQ7W] (noting that Laurie Garrett, an expert who predicted the pandemic, is predicting 36 months as a best-case event scenario for the coronavirus); Ewen Callaway, Delta Coronavirus Variant: Scientists Brace for Impact, NATURE (July 1, 2021), at 17, https://media.nature.com/original/magazine-assets/d41586-021-01696-3/d41 586-021-01696-3.pdf [https://perma.cc/5FC6-LXAV] (discussing the resurgence of COVID-19 in countries across the world due to the rise of viral variants, which may render current vaccines less effective at protecting against infection).

20. Karen Sloan, Law Schools That Planned to Return to Campus in Fall Are Reversing Course, LAw.COM (Aug. 5, 2020), https:/www.law.com/2020/08/05/law-schools-that-planned-toreturn-to-campus-in-fall-are-reversing-course/ [https://perma.cc/B527-RA47].

21. Tracking Colleges' Spring-Reopening Plans, CHRON. HIGHER EDUC. (Jan. 31, 2021), https://www.chronicle.com/article/tracking-college-spring-reopening-plans [https://perma.cc/3N2 B-9R98] (noting that only 16\% of colleges planned to teach primarily in person for the spring 2021 semester, and $40 \%$ planned to be primarily online).

22. See, e.g., Megan Rodriguez, Texas A\&M Summer Enrollment Number Down From Last Year, Up From 2019, BRYAN-COLLEGE STATION EAGLE (July 27, 2021), https:/theeagle.com /news/a_m/texas-a-m-summer-enrollment-number-down-from-last-year-up-from-2019/article_5e 0a07a0-ef36-11 eb-a12e-43ff873dc645.html [https://perma.cc/D9VE-DN6X] (noting that the 2021 
that they will in large part resume in-person teaching and learning in Fall 2021, many are also requiring proof of immunization for students, teachers, and staff. ${ }^{23}$ Nor are even those plans necessarily set in stone. Although many within the United States have chosen to be vaccinated against COVID-19, others have not, and dangerous and deadly variants of the virus are circulating. Indeed, many experts have raised significant concerns about the risks associated with the Delta variant. ${ }^{24}$ Some caution that even vaccinated individuals would be wise to continue to wear masks if they are in public or in large group settings. ${ }^{25}$ Given the recent experience with COVID-19, and given its continuing threat, schools and faculty have every reason to continue investing time and resources in ensuring that they can deliver quality online learning experiences to their students.

When comparing teaching and learning options, we must be realistic. Students understandably enjoy all that a campus-life has to offer, but it is unfair to suggest that the alternative to online teaching and learning is a carefree campus life full of all of the activities and amenities that existed pre-pandemic. Nor, as explained above, is emergency remote teaching the same as properlydesigned online education. ${ }^{26}$ Online courses necessarily do not have a brick-andmortar component, and some students may be more drawn to the classroom environment, ${ }^{27}$ but our experience has convinced us that one can deliver a

and 2020 summer semesters "had a similar amount of online courses offered" at Texas A\&M University); Mendocino College Continues Primarily Remote Instruction Through Summer 2021, WILLITS NEWS (Mar. 15, 2021, 11:19 AM), https:/www.willitsnews.com/2021/03/15/mendocinocollege-continues-primarily-remote-instruction-through-summer-2021/ [https://web.archive.org/ web/20210816193618/https://theeagle.com/news/a_m/texas-a-m-summer-enrollment-numberdown-from-last-year-up-from-2019/article_5e0a07a0-ef36-11 eb-al 2e-43ff873dc645.html] (discussing Mendocino College's announcement that it planned to continue offering primarily remote instruction through the summer 2021 semester).

23. Andy Thomason \& Brian O'Leary, Here's a List of Colleges That Will Require Students or Employees to Be Vaccinated Against Covid-19, CHRON. HighER EduC. (Aug. 13, 2021), https://www.chronicle.com/blogs/live-coronavirus-updates/heres-a-list-of-colleges-that-will-re quire-students-to-be-vaccinated-against-covid-19 [https://perma.cc/9RKU-NFZA] (identifying 736 US college campuses that are requiring students and/or staff to be vaccinated against COVID19).

24. Emily Anthes, The Delta Variant: What Scientists Know, N.Y. TIMES (June 22, 2021), https://www.nytimes.com/2021/06/22/health/delta-variant-covid.html [https://perma.cc/DR5V-G K68] (noting the Delta variant's higher transmissibility and evidence it may partially evade antibodies).

25. Id. (noting that WHO continues to advise mask-wearing by vaccinated individuals).

26. Because schools can deliver quality online education, it is unfair to suggest that should one's campus fail to reopen, deferral is the only option. See Byrne, supra note 18 (suggesting that the reason some students may seek to defer attending their graduate business schools if the fall semester is online is because some schools may not be shifting to well-designed online courses, but rather remote instruction using Zoom).

27. Studies indicate that students who are better at self-regulation may be more comfortable in the online learning environment than students who have lower levels of self-discipline. See 
quality learning experience online. Indeed, Dutton's own research based on anonymous student surveys and focus groups with students at IU McKinney who had taken asynchronous online classes at the law school--in a pre-COVID-19 world-produced evidence showing that students desired more online offerings. Student comments also showed that they believed that well-designed and organized online classes delivered a very high-quality learning experience comparable to that of high-quality live classes. ${ }^{28}$ Other law professors have similarly come to the conclusion that online classes can enhance student engagement and learning. ${ }^{29}$

Moreover, one cannot discount the possibility that because of COVID-19 and the continuing threat posed by variants, some students may desire a more flexible type of learning, causing an increase in a demand for asynchronous online offerings. Depending on their health or family situation, students may conclude that interacting with others on a populated campus is unduly risky or stressful-both to themselves and their family members. For those who are unvaccinated, and even for some who are vaccinated, there remains the possibility of a COVID-19 infection. After all, experts are not certain that the vaccines protect against any and all variants. ${ }^{30}$ Students may need to miss class-perhaps for weeks-to care for themselves or family members. The flexibility of online courses, especially asynchronous courses, could be a benefit to all until such time as COVID-19 is truly and fully behind us.

In this Article, we do not suggest that asynchronous law classes are "better" than courses taught in the classroom residentially. We both love teaching live and interacting with students. At the same time, we have both designed and

Yvonne M. Dutton et al., Assessing Asynchronous Online Learning in Law Schools: Students Say Online Classes Deliver, 96 DENV. L. REV. 493, 530 nn.256-58 (2019).

28. Id. at 521-530.

29. For example, Professor Kenneth Swift concluded that his online asynchronous Employment Law and Transactional Drafting courses provided more opportunities for students to engage in active and cooperative learning and assessment than they would have had in the classroom setting. Kenneth R. Swift, The Seven Principles for Good Practice in (Asynchronous Online) Legal Education, 44 MITCHELL HAMLINE L. REV. 105, 111-13, 161 (2018); see also Susan D. Landrum, Drawing Inspiration from the Flipped Classroom Model: An Integrated Approach to Academic Support for the Academically Underprepared Law Student, 53 DUQ. L. REV. 245, 27275 (2015).

30. Michael Erman, Booster May be Needed for J\&J Shot as Delta Variant Spreads, Some Experts Already Taking Them, REUTERS (June 28, 2021), https://www.reuters.com/business/health care-pharmaceuticals/booster-may-be-needed-jj-shot-delta-variant-spreads-some-experts-alreadytaking-2021-06-25/ [https://web.archive.org/web/20210816125931/https://www.reuters.com/busi ness/healthcare-pharmaceuticals/booster-may-be-needed-jj-shot-delta-variant-spreads-some-ex perts-already-taking-2021-06-25/] (noting that efficacy against the Delta variant varies across vaccines and dosage regimes); Apoorva Mandavilli, In a Handful of States, Early Data Hint at Rise in Breakthrough Infections, N.Y. TIMES (Aug. 17, 2021, 6:18 PM), https:/www.nytimes.com /2021/08/17/health/covid-vaccinated-infections.html [https://perma.cc/9BCW-J4AY] (discussing the increase in infections among the fully vaccinated after the Delta variant's arrival in the US). 
offered online asynchronous courses to accommodate student demand. Based on that experience, we offer some guidance on how to develop and implement an effective asynchronous distance-learning course for law students for those academics who are transitioning to online courses because of this pandemic. In Part II, we briefly introduce the topic of online learning in law schools and describe some of the advantages and disadvantages of both synchronous and asynchronous courses. In Part III, we share our own experiences in creating online courses with the assistance of our university's instructional designers and highlight course features that we believe, and that students have confirmed, aid in delivering high-quality and engaging learning experiences. We sincerely hope that professors are not forced to teach their students remotely in the future because of a pandemic. To the extent that schools wish to offer distance-learning options to their students, we hope that this Article provides some useful guidance.

\section{ONLINE LEARNING IN LAW SCHOOLS}

\section{A. Online Offerings in Law Schools Expand with ABA Approval}

Even pre-pandemic, the demand for online education in law schools was growing in the United States. ${ }^{31}$ Our own law school began its online programming launch in January $2015 .{ }^{32}$ Over the past several years, the number of courses offered online at IU McKinney has steadily grown, such that as of January 2020 , students may select from among approximately 20 courses. ${ }^{33}$ That

31. In a review of law school websites as of July 2018, at least 31 schools were offering some number of online courses as part of their law school curriculum. This number is based on searching the websites of each of the top 100 law schools ranked by U.S. News and World Report. Due to ties, this covered ranks 1 to 99 . A limitation of this approach is that not all law schools may mention their online offerings on their websites, and newly approved or planned online courses may not yet have been added to the websites. A handful of law schools offer hybrid programs, allowing students to complete some coursework online and some in the classroom. See, e.g., Nina A. Kohn, Jinteractive: An Online Law Degree Program Designed to Expand Access to Justice, 90 N.Y. STATE BAR ASs'N J. 30, 30 (Sept. 2018); Karen Sloan, Syracuse's New Online JD Portends Popularity of Hybrid Programs, N.Y. L.J. (Jan. 9, 2019, 2:23 PM), https://www.law.com/newyork lawjournal/2019/01/09/syracuses-new-online-j-d-portends-popularity-of-hybrid-programs/

[https://perma.cc/LJ45-GT5N] (discussing the launch of the hybrid online JD program at Syracuse); Paul Caron, Denver Is the Eighth Law School to Offer a Hybrid J.D., TAXPROF BLOG (Aug. 23, 2018), http://taxprof.typepad.com/taxprof_blog/2018/08/denver-is-eighth-law-schoolto-offer-hybrid-jd.html [https://perma.cc/6N8Y-JQRD] (listing law schools with hybrid online JD programs); Low Schools With Online and Hybrid J.D. Programs, HBCU PRE-LAW, http://www.hbcuprelaw.org/law-schools/law-schools-with-online-and-hybrid-j-d-programs/ [https://perma.cc/U726-LEGH] (listing hybrid online JD programs).

32. See, e.g., Cynthia Matson Adams, et al., Upward! (Higher): How a Law Faculty Stays Ahead of the Curve, 51 IND. L. REV. 413, 413 (2018).

33. List of Online Courses, IND. UNIV. ROBERT H. MCKINNEY SCH. OF LAw, https://mc kinneylaw.iu.edu/courses/online.cfm [https://perma.cc/VL3Q-JU8P]. 
schools like ours are expanding their online offerings is not surprising. The flexibility inherent in online courses helps students balance other competing interests, such as work, family, and child-care commitments. ${ }^{34}$ That flexibility also allows students to pursue new opportunities, such as internships and externships, all while continuing to complete the law school curriculum. ${ }^{35}$ This is something graduate business schools have recognized, with many of the most prestigious even offering fully online MBA programs. ${ }^{36}$

One decision that professors or institutions will have to make when designing an online course is whether to deliver it synchronously or asynchronously. In the synchronous course, students must be online at the same time as the professor during specific class hours. ${ }^{37}$ The asynchronous course, by contrast is time-shifted, meaning that students and the professor do not meet online in real-time. Instead, students complete modules and assignments at their own pace and at a time of their choosing. ${ }^{38}$

In all cases, law schools delivering online courses must comply with $\mathrm{ABA}$ rules. The ABA approves of both synchronous and asynchronous online classes, ${ }^{39}$ with the stipulation that asynchronous courses must include interaction that is

34. See Dutton et al, supra note 27 , at 521, 528-29 (referencing anonymous student surveys and focus group results emphasizing flexibility as one of the benefits students appreciated from an online class).

35. See Max Huffman, Online Learning Grows Up-and Heads to Law School, 49 IND. L. REV. 57, 67 (2015) (suggesting that with online classes, a student could do an internship out-ofstate while still completing a law degree at the home institution).

36. See, e.g., Best Online MBA Programs, U.S. NEwS \& WORLD REP., https://www.usnews .com/education/online-education/mba/rankings [https://web.archive.org/web/202102041704 09/https://www.usnews.com/education/online-education/mba/rankings]; Online MBA Admissions, UNIV. OF MICH. ROSS SCH. OF BUS., https://michiganross.umich.edu/graduate/online-mba /admissions [https://perma.cc/3H3Z-7AHC].

37. Synchronous vs Asynchronous Learning, ELEARNERS, https://www.elearners.com/educa tion-resources/degrees-and-programs/synchronous-vs-asynchronous-classes/ [https://perma.cc/4F 2B-C94M].

38. See Devon Haynie, Decide Between Live, Self-Paced Online Classes, U.S. NEWS \& WORLD REP. (Jan. 9, 2015, 9:30 AM), https:/www.usnews.com/education/online-education /articles/2015/01/09/decide-between-live-self-paced-online-classes [https:/web.archive.org/web /20201110085731/https://www.usnews.com/education/online-education/articles/2015/01/09/de cide-between-live-self-paced-online-classes] (stating that asynchronous courses let students "sign on and view course readings or videos when they please").

39. According to the ABA, an online course is one where "students are separated from the faculty member or each other for more than one-third of the instruction and the instruction involves the use of technology to support regular and substantive interaction among students and between the students and the faculty member, either synchronously or asynchronously." ABA STANDARDS AND RULES OF PROCEDURE FOR APPROVAL OF LAW SCHOOLS 2017-2018 § 306(a) (AM. BAR ASS'N 2018), https://www.americanbar.org/content/dam/aba/publications/misc/legal_education /Standards/2017-2018ABAStandardsforApprovalofLawSchools/2017_2018_standards_chapter3 .authcheckdam.pdf [https://perma.cc/8GL7-AXBA]. 
similar in kind and quality as that offered in live law classes. ${ }^{40}$ Pursuant to Standard 306, online courses must be "approved as part of the school's regular curriculum approval process." 41 Those courses must also comply with Standard 302 's learning outcomes requirements, which stress competency in areas such as knowledge of the law, legal analysis and reasoning, professional responsibility, and other legal skills the law school may find appropriate. ${ }^{42}$

In August 2018, the ABA updated its Standard 306 and expanded to 30 the number of online-course credits that law students may apply towards their J.D. degree-with a maximum of ten such credits in the first year of law school. ${ }^{43}$ The ABA made this change based on its "belief that legal education instruction can be delivered as effectively by distance education as by instruction in the traditional manner." 44 Because the ABA has recognized that schools can effectively deliver legal education online, and in order to respond to the pandemic, the ABA removed Standard 306 from the 2020-21 ABA Standards to increase the amount of online programming law schools may offer. ${ }^{45}$

\section{B. Synchronous Courses}

Many professors transitioned to synchronous online courses during the emergency shift to online teaching in Spring 2020 and Fall 2020. At our institution, for the three-weeks left in law school before summer break 2020, most professors delivered their courses during the regularly-scheduled class time

40. See id. $\S 306$ (d) (stating that asynchronous courses must offer an "opportunity for regular and substantive interaction between [the] faculty member and student and among students; [and include] ... regular monitoring of student effort by the faculty member...and opportunity for communication about that effort").

41. Id. $\S 306(\mathrm{~b})$.

42. Id. $\S \S 302,306(\mathrm{~d})(3)$.

43. ABA STANDARDS AND RULES of PROCEDURE FOR APPROVAL OF LAW SCHOOLS 20182019 § 306(e) (AM. BAR ASS'N 2019), https://www.americanbar.org/content/dam/aba/publications /misc/legal_education/Standards/2018-2019ABAStandardsforApprovalofLawSchools/2018-2019 -aba-standards-rules-approval-law-schools-final.pdf [https://perma.cc/P7BD-LTUY].

44. Memorandum from Pamela Lysaght, Chair, Standards Rev. Comm., Am. Bar Ass'n, to Dean Maureen O'Rourke, Chair, Council of the Section of Legal Education and Admissions to the Bar, Am. Bar Ass'n (Oct. 12, 2017), https:/www.americanbar.org/content/dam/aba/administrative /legal_education_and_admissions_to_the_bar/council_reports_and_resolutions/November2017 CouncilOpenSession/2017_nov_memo_re_proposed_changes_to_standards.authcheckdam.pdf [https://perma.cc/R54B-6WQ4].

45. See ABA STANDARDS AND RULES OF PROCEDURE FOR APPROVAL OF LAW SCHOOLS 2020-2021 306 (AM. BAR ASS'N 2020), https:/www.americanbar.org/content/dam/aba/adminis trative/legal_education_and_admissions to_the_bar/standards/2020-2021/2020-21-aba-standardsand-rules-for-approval-of-law-schools.pdf [https://perma.cc/YCN5-G2XX]. In its February 2020 Guidance in response to the pandemic, the ABA noted that law schools may deviate from that standard and others when responding to an emergency or other disaster. See Managing Director's Guidance Memo, supra note 3. 
synchronously using the Zoom platform. ${ }^{46}$ Delivering classes synchronously has certain advantages. The video and audio components allow the professor and students to be seen and heard. Thus, interaction occurs much as it does in a live setting: the professor poses questions for the students to answer and the students ask questions of the professor. Zoom even has a hand-raising feature, allowing students to indicate the need to ask a question, which can be helpful if a student's camera is off or if the class is very large. Zoom's chat feature allows all participants to pose questions or engage in discussion. Professors can also share their screen, use a white board, put students into breakout groups for discussions, and allow students to share their screens for presentations. ${ }^{47}$ In addition, Zoom allows the professor to record the class for later review by students ${ }^{48}$-a feature helpful for students who missed the class or who may want to review it further on their own time. For all of these reasons, some professors and students are partial to synchronous classes. ${ }^{49}$

On the other hand, synchronous classes can pose challenges for both the professor and the students. For the professor, those challenges primarily relate to (1) student learning and engagement and (2) privacy and security. As to student learning and engagement, there is some evidence that students have more difficulty paying attention to video classroom sessions-especially for any significant period of time. ${ }^{50}$ Nor does the video-link classroom setting make it easy for the professor to engage students in discussion or identify when students are losing interest, especially in larger classes. Limitations on the number of faces that can been seen at one time on Zoom and similar platforms necessarily means that in a larger class, the professor cannot see all students at one time, nor can she likely get a sense of the "mood" of the class as a whole. ${ }^{51}$ Discovering

46. See ZoOM, https://zoom.us [https://perma.cc/B7H3-Z5HJ].

47. Rebecca Bellan, What You Need To Know About Using Zoom, ForBes (March 24, 2020, 8:57 PM), https://www.forbes.com/sites/rebeccabellan/2020/03/24/what-you-need-to-know-about -using-zoom/ [https://perma.cc/9ULR-SFUZ].

48. Id.

49. See, e.g., Ellen S. Podgor, Teaching a Live Synchronous Distance Learning Course: A Student Focused Approach, 2006 U. ILL. J. L. TECH. \& POL'Y 263, 263 (2006) (discussing a synchronous online international criminal law course); Haynie, supra note 38 (suggesting that students in synchronous classes have the feeling of being in a regular classroom).

50. Yoshiko Iwai, Online Learning during the COVID-19 Pandemic, SCIENTIFIC AMERICAN (March 13, 2020), https://blogs.scientificamerican.com/observations/online-learning-during-thecovid-19-pandemic/ [https://perma.cc/7B94-KCPB] (discussing a university student's many distractions during a Zoom class held during the pandemic, including the many noises from classmates' locations when their microphones are not muted).

51. See Podgor, supra note 49, at 271 (describing author's experience of teaching a synchronous course to her home institution in Georgia and to another institution in Kentucky and noting that she would do it again with modifications, such as having better technical assistance available and limiting student enrollment so that she could more easily see all students on her screen). 
that students are confused is a relatively easy task in a live classroom because students will raise their hands, start fidgeting and talking amongst themselves, or simply look perplexed. The professor can then pause to clarify any confusion. On Zoom, the professor has to scan the participants list for raised hands or follow messages over the chat function while also trying to lecture or engage in Socratic dialogue. ${ }^{52}$ In short, the professor may not even notice having lost students' attention. ${ }^{53}$ Yet this risk is real: students attend synchronous classes from home or work-where other distractions compete for their attention. To guard against inattention, the professor may have to set norms for engagement during the video classroom-such as requiring all or some students to speak during the class session.

Professors should also be ready to address the privacy and security risks inherent in the video-link classroom. ${ }^{54}$ During spring 2020 , some classes were interrupted by "Zoombombing," 55 a practice whereby an uninvited attendee disrupts the class and shares offensive materials. A waiting room option may help prevent against that. Professors must also consider how to protect against the possibility that a participant's camera will intentionally or unintentionally project images that may be offensive to others on the video call. ${ }^{56}$ Recording

52. Kelsey J. Griffin, 'A Decidedly Suboptimal Set of Circumstances': Harvard Law Professors Evaluate Online Instruction, HARV. CRIMSON (April 1, 2020), https://www.thecrimson .com/article/2020/4/1/harvard-coronavirus-law-school-zoom/ [https://perma.cc/YGY7-R3GZ] (noting that some professors reported difficulty "reading the room" while on Zoom and keeping track of raised hands while also lecturing).

53. Professors may not even know that students have stepped away from the Zoom meeting. "Innovators" have shared the secret of how to post a video of oneself nodding and looking attentive into Zoom's virtual background feature. See Bellan, supra note 47.

54. Brian X. Chen, The Lesson We Are Learning From Zoom, N.Y. TMMES (April 8, 2020), https://www.nytimes.com/article/zoom-privacy-lessons.html [https://perma.cc/7UMV-G758] (discussing generally some potential privacy and security issues with using Zoom); Glenn Fleishman, Here's When You Can Trust Zoom, and When You shouldn't, FAST COMPANY (April 13, 2020), https://www.fastcompany.com/90488717/can-you-trust-zoom [https://perma.cc/99GE$84 \mathrm{XM}$ ] (discussing potential privacy and security issues Zoom users may encounter).

55. See Rae Hodge, Zoom Security Issues: Zoom Buys Security Company, Aims for End-toEnd Encryption, CNET (May 7, 2020, 12:23 PM), https:/www.cnet.com/news/zoom-securityissues-zoom-buys-security-company-aims-for-end-to-end-encryption/ [https://perma.cc/J4LF-3A J8] (defining Zoombombing); Ashleigh Panoo, Zoombomber Crashes Fresno State Session with Child Porn, Professor Confirms, FRESNO BEE (April 23, 2020, 12:28 PM), https://www.fresnobee .com/news/local/article242232691.html [https://web.archive.org/web/20201031132510/https://w ww.fresnobee.com/news/local/article242232691.html] (referencing a Zoombombing incident at Fresno State).

56. Is Zoom a Classroom?, ABOVE THE LAW (May 5, 2020), https://abovethelaw.com/2020 /05/is-zoom-a-classroom/ [https://perma.cc/HTY2-B4EG] (referencing some potential issues associated with holding classes over Zoom, including that participants display racist or other offensive images or materials); Isabel Vincent, Embarrassing Moments from Online Teaching, Video Conferences amid Coronavirus, N.Y. Post (March 21, 2020, 5:15 PM), https://nypost.com /2020/03/21/embarrassing-moments-from-online-teaching-video-conferences-amid-coronavirus/ 
classes is another matter for further exploration. Recording has the benefit of preserving class content for student use. However, as some commentators note, that recording may impinge on students' privacy if the recording includes student comments and content. ${ }^{57}$ Understandably, some students may not want their classroom comments, or their responses to Socratic dialogue, preserved on video. As we professors know, many students do not enjoy having their classmates watch them during a live Socratic session-which at least is viewed only once and fleetingly. Indeed, a policy of taping synchronous classes could hinder participation, as students may not want to have any lasting reminders of less-than-brilliant questions or answers. ${ }^{58}$ These issues suggest that law schools would be wise to devise a sound and particularized policy about whether and under what circumstances professors should record and share the tapes of any synchronous classes. ${ }^{59}$

Synchronous classes also pose unique challenges to students. At a very basic level, attending live video classes requires a strong internet connection, something that is lacking at times even for those of us who have subscribed to receive that service. ${ }^{60}$ Nor will every student have access to a location that allows them to have a private video-link call with their professor and other students in attendance. ${ }^{61}$ Students may also experience much more fatigue attending classes over Zoom, than attending live classes. Experts explain that the fatigue is a result of the need to focus one's attention so directly at the screen and on the speaker. One has to work harder to process non-verbal cues like facial

[https://perma.cc/64D7-H482] (reporting that a Fordham University professor had to pause the video recording of his Zoom class when he saw a nude man rising from a bed in the background of a student's video feed).

57. See Diane Klein, And Now, Charybdis: The Risks of Recording (Especially Synchronous) Classes, DORF ON LAW (March 25, 2020, 8:59 AM), http://www.dorfonlaw.org/2020/03/and-nowcharybdis-risks-of-recording.html [https://perma.cc/HH45-YDNW] (discussing the risks of taping synchronous classes in which students participate).

58. Id.

59. See Alexis Anderson, Classroom Taping Under Legal Scrutiny-A Road Map for a Law School Policy, 66 J. LEGAL EDUC. 372 (2017) (suggesting generally that for a variety of legal reasons, law schools consider a policy on whether and when to permit taping classes in which students participate).

60. Joel Santo Domingo, How to Make Your Wi-Fi Suck Less While Working from Home, WIRECUTTER (March 18, 2020), https://thewirecutter.com/blog/make-wi-fi-suck-less-workingfrom-home/ [https://perma.cc/M3WT-GLD2] (noting that Zoom and Webex consume the most bandwidth).

61. Jason DeParle, For Americans Living in Poverty, Keeping 6 Feet Apart Is a Luxury Beyond Reach, N.Y. TIMES (April 12, 2020), https://www.nytimes.com/2020/04/12/us/politics/corona virus-poverty-privacy.html [https://perma.cc/FUJ4-4YA4] (discussing the challenges faced by a college student living in a friend's house with ten other people now that he cannot be in his dorm room). 
expressions and body language. ${ }^{62}$ Some experts suggest that "the distortions and delays inherent in video communication can end up making [one] feel isolated, anxious and disconnected." 63 These stresses associated with attending videolink classes, especially in the context of a pandemic, should encourage those planning curriculum to avoid a whole semester of only synchronous classes.

Finally, synchronous classes lack flexibility-something many students may need even more of due to the COVID-19 pandemic. Some students will find attending a class during a fixed time-slot difficult: for instance, students with other responsibilities, and those who may be living in different time zones. In fact, the lack of flexibility inherent in synchronous classes is something that law schools and law professors should seriously contemplate before offering students a panoply of such courses. Because of the pandemic and its resulting effects, more students may need to work to afford tuition. Students may also have children at home due to a lack of childcare or closed schools. Nor should we ignore the possibility that some students, faculty, or their loved ones may become sick, making attending or offering synchronous classes difficult or impossible.

\section{Asynchronous Courses}

Asynchronous online programming, by contrast, offers the benefit of increased flexibility to students who might have difficulty attending live classroom sessions because of illness, childcare, family or work obligations. ${ }^{64}$ Students do not meet online at any set time with the professor or other students, and instead they watch recorded lessons and complete weekly assignments designed to assess their understanding and mastery of learning outcomes for the

62. Manyu Jiang, The Reason Zoom Calls Drain Your Energy, BBC (April 22, 2020), https://www.bbc.com/worklife/article/20200421-why-zoom-video-chats-are-so-exhausting [https://perma.cc/S5TA-6AY5].

63. Kate Murphy, Why Zoom is Terrible, N.Y. TIMES (April 29, 2020), https://www.nytimes .com/2020/04/29/sunday-review/zoom-video-conference.html [https://perma.cc/JE3U-QSKQ].

64. See, e.g., Steven C. Bennett, Distance Learning in Law, 38 SETON HALL LEGIS. J. 1, 6-7 (2014) (explaining how the flexibility of online learning benefits students with other obligations outside of school); Haynie, supra note 38 ("Many online students are juggling work and family commitments, and they don't always have time to log in at a certain hour"); Swift, supra note 29, at 157-58 (explaining that asynchronous courses allow nontraditional students to attend courses less frequently during the week and control when they will engage with the material). 
lesson. ${ }^{65}$ Course content is offered via a learning management system ${ }^{66}$ (IU's learning management system is Canvas), ${ }^{67}$ with a course website containing lessons organized by "modules." Through the tools available on the learning management system, the professor is able to provide regular feedback on student assignments. Although students must submit assignments by a specific date, they may choose the day or time within the week to watch lectures, complete readings, and work on actvities without attending a live classroom meeting. ${ }^{68}$

The courses that each of us deliver online at IU McKinney are asynchronous and can serve to illustrate the discussion above. On the Canvas site, the students go to a course website where they are greeted by a Home Page that generally introduces them to the course content, the professor, and course guidelines. On the course website, students access modules, which correspond to either a classroom session or a classroom week. When students click on the module, they arrive at a page which sets out the content they need to complete that lesson. For example, the module page includes the learning objectives for the lesson and any reading assignments, as well as links to short video-taped lectures by the professor, accompanied by PowerPoint slides. That page can also include optional readings for interested students, such as links to recent news articles relevant to the topic. Depending on the course and the lesson, we may also link to outside videos: for example, videos reporting on current or past events referenced in the reading or those reporting on recent court decisions. ${ }^{69}$ Also

65. See, e.g., Huffman, supra note 35 , at $70-84$ (describing author's online asynchronous Comparative and International Competition Law course and how he uses a course paper and online quizzes followed by discussion about common mistakes as effective assessments to ensure student learning of material); Swift, supra note 29, at 112-13 (explaining various assignments assigned in author's asynchronous Employment Law and Transactional Drafting courses, such as questions about the reading, short answer questions to apply knowledge, group discussion questions, researching applicable law, and drafting assignments); Max Huffman \& Cynthia Adams, Online Simulation Courses, 51 IND. L. REV. 418, 422 (2018) (describing development of online contract drafting simulation); Margaret Ryznar, Assessing Law Students, 51 IND. L. REV. 447, 450 (2018) (describing assessment of students in online Trusts and Estates course); Mark L. Shope, Real World Problem-solving in the Digital Classroom, 51 IND. L. REV. 455, 456 (2018) (describing assessments in an online International Business Transactions course).

66. See William Fenton, The Best (LMS) Learning Management Systems, PC MAG (Jan. 12, 2018), https://www.pcmag.com/picks/the-best-lms-learning-management-systems [https://perma .cc/4F9N-SCV7] (describing several learning management systems used in higher education used "to develop and assign course content, track student progress, and measure and report student outcomes.").

67. See The Canvas Learning Management Platform, INSTRUCTURE, https:/www.instructure .com/canvas/higher-education/platform [https:/perma.cc/USK9-XKY4].

68. Synchronous vs Asynchronous Learning, supra note 37 (explaining that "[s]tudents are given a timeframe-it's usually a one-week window-during which they need to connect to their class at least once or twice.").

69. See generally id. (noting that asynchronous courses may contain supplemental materials to enhance student learning, such as PowerPoints, documents, podcasts, and videos). 
posted on the page are links to weekly assignments designed to assess student learning. Assignments vary depending on the type of course we are teaching and the lesson's learning objectives. But, they have included quizzes, discussion questions, and other assessments requiring a written submission or video presentation.

That all students have to complete weekly assessments in asynchronous classes in order to facilitate the required interaction is a positive feature of this type of course. In many live law school classes, especially those larger classes that use Socratic dialogue as the main teaching method, only a handful of students will actively participate during a class session. ${ }^{70}$ Even if some students volunteer comments or ask questions, in any given classroom session the participation of many students will be more passive in nature. A great many students will listen to the professor and their colleagues and take notes. In the asynchronous class, every student must participate weekly: completing quizzes, writing discussion posts, and any other oral or written assignments. ${ }^{71}$ Indeed, one student who responded to one of Dutton's anonymous surveys explained that this feature of the online class was especially valuable for more introverted students who would be loathe to participate voluntarily in a live classroom setting. In the online setting, however, the student had no choice but to complete assignments, including posting to discussion boards that were shared with classmates.

Weekly assessments in asynchronous courses provide students with another benefit-regular feedback. For many law students, this is actually a welcome novelty, given that in many courses the student only receives feedback from a final exam. In our online courses, we regularly provide students with feedback. This sometimes takes the form of individualized comments on an assignment, and sometimes automatic feedback from quizzes that can "grade themselves" or other assignments for which we offer a "sample answer." We also post group feedback on each assignment, which gives students a pulse for how they are doing in much more regular intervals than our usual live law school classes. Feedback can also come in the form of self-reviews based on a rubric provided

70. See, e.g., Douglas L. Leslie, How Not to Teach Contracts, and Any Other Course: Powerpoint, Laptops, and the CaseFile Method, 44 ST. LoUIS U. L. J. 1289, 1297-98 (2000) (quoting an interview with Prof. Martin Louis in which Louis acknowledges that the attention of other students may well be drifting while he dialogues with a single student); Peggy Cooper Davis \& Elizabeth Ehrenfest Steinglass, A Dialogue About Socratic Teaching, 23 N.Y.U. REV. L. \& SoC. CHANGE 249, 275 (1997) (noting that students who are not being called on may be feeling relief rather than actively listening); see also Simon Canick, Infusing Technology Skills into the Law School Curriculum, 42 CAP. U. L. REV. 663, 696 (2014) (suggesting that professors encourage their students to post comments with a class hashtag to keep them engaged when they are not the student "on call").

71. See Selma Koc Vonderwell \& Marius Boboc, Promoting Formative Assessment in Online Teaching and Learning, TECHTRENDS, July/Aug. 2013, at 22 (discussing techniques to create engagement in online asynchronous courses). 
by the professor or a sample answer. Dutton has also used peer reviews, where she requires students to comment on another student's work based on a rubric she provides which focuses the student in on certain components of the submission.

We understand that providing regular feedback to students-particularly individualized feedback-is burdensome on the professor. It is, however, a feature that students repeatedly referenced as one they most valued in the asynchronous courses they took at IU McKinney. ${ }^{72}$ Nor does all feedback need to be time-consuming for the professor. In courses with larger enrollments, a professor may decide that more frequent quizzes with built-in answers or problems with sample answers may be more tenable than giving individualized feedback to every student each week. Finally, regular feedback need not only exist in asynchronous classes. Professors could incorporate it into synchronous online classes as well—-something we would highly recommend.

One challenge that the asynchronous course shares with the synchronous course is capturing the student's attention remotely. ${ }^{73}$ The number of tools available in the asynchronous environment to engage students in the learning process, however, are many. As noted, to assess student learning, we have created quizzes, discussion posts, papers, problem sets, video-taped oral arguments, video-taped presentations, and group exercises. To add more variety, we and other professors at IU McKinney have even created and role-played in video skits that serve as the basis for student assignments based on the "hypothetical" depicted in the skit. For her online International Criminal Law class, Dutton and another colleague created a video about best practices for oral argument, with demonstrations by moot court students. Dutton has students in her class watch the video before they create their own oral argument videos. We also seek out other video materials to help encourage student engagement with the material. For instance, in Dutton's online Comparative Law class, she posts

72. For example, one student explained that having the regular assessments and "getting that feedback throughout the semester is something you don't get in $95 \%$ of the in-class courses here, and I think for me it has helped my learning and has solidified my understanding of the material in these classes, because I'm checking myself along the way." See Dutton et al., supra note 27, at 528. See also Margaret Ryznar \& Yvonne M. Dutton, Lighting a Fire: The Power of Intrinsic Motivation in Online Teaching, 70 SYRACUSE L. REV. 74, 101 (2019) (noting that anonymous student surveys from students in Dutton's and Ryznar's classes referenced regular feedback as one of the features of the online asynchronous classes they most appreciated and that best facilitated learning).

73. Karl K. Szpunar et al., Mind Wandering and Education: From the Classroom to Online Learning, FRONTIERS IN PSYCHOLOGY (Aug. 1, 2013), https:/www.frontiersin.org/articles /10.3389/fpsyg.2013.00495/full [https://perma.cc/9VJY-NWHM] (reviewing studies of mind wandering during both live and online lectures); Rachael N. Blasiman et al., Distracted Students: A Comparison of Multiple Types of Distractions on Learning in Online Lectures, 4 SCHOLARSHIP OF TEACHING \& LEARNING IN PSYCHOLOGY 222, 222 (2018) (testing six distractions students might experience while undertaking online learning at home and finding impairment resulting from all of them). 
a video of Justice Sotomayor talking about citing to foreign law; a video about William the Conqueror; a video showing "question time" in UK Parliament; a video about the Old Bailey in London; a BBC documentary about the UK Supreme Court; a video about the Old Bailey in London; and videos from the various European Union institutions explaining their institution. One great thing about these videos is that they "show" what we can only talk about, connecting the course to the real world - albeit on video. ${ }^{74}$ These are but some of the ways one can encourage student engagement and learning in an asynchronous online law course.

A challenge unique to the asynchronous class, of course, is that the students and the professor do not convene at the same time to interact spontaneously as they do in the live classroom. This can also mean that students miss the opportunity to easily stop the professor to get clarification or ask a question. ${ }^{75}$ In an asynchronous class, the student will have to ask clarification questions by email or in a Zoom session with the professor. We each offer Zoom office hours by appointment, although we have found that many students do not take advantage of this option.

To promote greater spontaneous interaction, the professor can include some synchronous sessions in an otherwise asynchronous course. Dutton, in fact, tried this when she first started teaching Comparative Law online. She scheduled three synchronous meetings so that students would have the opportunity to Zoom with experts in Chinese Law, French Law, and Islamic Law. For two reasons, Dutton has since removed those Zoom meetings from her course. First, in some cases, the internet connection was not strong-possibly because the experts were speaking from China and other international locations. Second, students did not take the opportunity given them to ask questions of the experts, even though time was built in for questioning. Dutton suspects that students did not feel comfortable speaking up on Zoom.

There is another possible reason that students did not speak up. Anonymous student surveys in this and another online class where Dutton scheduled a couple of synchronous meetings generally showed that her students preferred a wholly asynchronous class. Scheduling flexibility was important to them, they had signed up for an asynchronous course, and they did not want this scheduled intrusion. Some students simply may not need or want real-time interaction in an online course. Anonymous student surveys in Dutton's courses support this

74. See Dutton et al., supra note 27 , at $527 \mathrm{n} .228$ (referencing student focus group comments indicating that students find video content engaging); Ryznar \& Dutton, supra note 72, at 104-05 (referencing anonymous student survey comments in Dutton's Online Comparative Law class stating that the supplemental videos were engaging and added an extra learning component to the class).

75. See Dutton et al., supra note 27 , at $524-25$ (referencing student focus group comments indicating that some students missed the opportunity in online classes to stop the professor and ask a question immediately as something required clarification). 
conclusion. In response to a question Dutton asks about whether students feel connected to the other students and the professor, many students reported that they either felt sufficiently connected or that they were not desiring connection through an online course in any event. Many also said that they felt connected to the professor through the regular feedback. ${ }^{76}$ One caveat is that in Dutton's online courses, some students already knew some of their classmates or had already taken live classes with the professor. Also, students were typically only taking one online class in a semester, which meant they were already getting a lot of live interaction at the law school. Thus, in an environment where online courses only make up a part of the student's law school experience, connection in an online class may hold minimal importance.

When deciding whether to offer online classes synchronously or asynchronously, professors should be guided by the learning objectives for the course overall and for each weekly module. Our experience is in designing and delivering asynchronous courses, and we chose that format because of its many advantages as outlined above. We should note that the asynchronous courses we have created are for various "specialty courses." Dutton has taught International Criminal Law, Comparative Law, and International Law online asynchronously at the law school. Mohapatra has taught Introduction to Health Law and Policy. With that said, we have colleagues who have taught large "black letter law" courses such as Trusts and Estates and Professional Responsibility very successfully using the asynchronous format. In fact, Mohapatra teaches Torts in the live classroom, and she has used online asynchronous modules for some make-up classes. The classes consisted of recorded lectures on topics such as contributory negligence, and students were required to complete problems to help them practice applying concepts. Students reported enjoying the modules and the opportunity to assess their mastery of course content and skills with immediate feedback. In short, professors should be able to design high-quality, effective asynchronous online courses, even for large bar-tested classes.

\section{BUILdING THE ONLINE COURSE}

With support from our institution, each of us was able to develop our asynchronous online courses with guidance from an instructional design consultant. ${ }^{77}$ Even though we had both been teaching in the classroom for years,

76. See Ryznar \& Dutton, supra note 72 , at 102 (referencing anonymous student comments in Dutton's online Comparative Law class stating students felt connected to the professor through feedback).

77. We had access to instructional design consultants from Indiana University-Purdue University Indianapolis (IUPUI) Center for Teaching and Learning. See CENTER FOR TEACHING AND LEARNING, https://ctl.iupui.edu [https://perma.cc/4WQ6-BUT3]; see also eLearning Design \& Services, University Information Technology Services (UITS); see also ELEARNING DESIGN AND SERVICES, UITS, https://teachingonline.iu.edu/about/eds/index.html [https://perma.cc/489GHY53]. 
we found the experience extremely enlightening, and we recommend that law schools connect faculty members to such resources. Our designers were trained in both pedagogy and technology. ${ }^{78} \mathrm{With}$ their help, we learned how to translate our classroom teaching into the online environment and effectively use technology to engage students and facilitate learning.

In an ideal world, in our experience and opinion, designing a high-quality asynchronous online course is an endeavor which requires at least six-months of steady work (we estimate between 200-300 hours of work). Among other things, we suggest settling on learning objectives for each module, writing scripts for lectures (which should be shorter and focused to keep student attention); taping those lectures; and creating appropriate assignments to assess student learning of the module learning objectives. Then there is the technology: one has to master the learning management system in order to create module pages, quizzes, and assignments. And one has to upload all of the materials, including readings and videos to the module pages, organize that content, and ensure that everything is accessible and that links work for students. Instructional designers helped us talk through the different options for assignments. At $\Pi \mathrm{U}$, the designers also did much of the technical work associated with making the course content look organized, appealing, and professional. Of course, this is just one common approach, not a universal one. Law schools handle the course build process in a variety of ways and build diverse forms of asynchronous educational materials.

We understand that when responding to an emergency situation, such as that posed by the pandemic, some professors may have only a few months to create a high-quality online course. We still believe this can be done. One may have to sacrifice some technological "bells and whistles," but one can still achieve an engaging learning experience for students. Also, it bears noting that one need not have every aspect of the course completed before the semester commences. One can continue to build out later modules during the semester while the course is running.

For those faculty interested in teaching asynchronously, we summarize some of the main takeaways from working with our instructional design consultants. We first suggest that professors consider their learning objectives and organize their course according to such objectives. We then describe how we create and record lectures and engaging and varied assignments complete with feedback opportunities.

78. As indicated by a search of "instructional designer" job listings at ChronicleVitae.com on May 7, 2020, online course designers are typically expected to have at least a bachelor's degree and often a master's degree in areas such as Instructional Design, Curriculum Design, Educational Technology, or Learning Engineering, as well as experience in the field. 


\section{A. Learning Objectives}

When developing any course, professors should tell students what they expect them to learn in the course, as well as in each lesson or module. These so-called learning objectives typically require the professor to think in terms of outcomes, based on action words such as "explain," "describe," "understand," "discuss," and "analyze."79 Grounding the course and lessons in learning objectives aids the professor in determining the material and skills students should master. ${ }^{80}$ One must ask: "How will students attain the knowledge and skills from the material included in the module?" Answering that question will help one decide what technology to use or assignments to design to assess understanding of the material and successful achievement of the learning objectives. Considering the role of technology also means thinking about how one might use that technology creatively to serve the students so that they are more engaged in the learning process. Creativity is encouraged, because as noted, professors must compete for the students' attention in the online learning environment.

For example, in Mohapatra's Introduction to Health Care Law and Policy, she listed the following learning objectives for a lesson about health privacy laws at the state and federal level:

1) Understand how HIPAA applies to covered entities;

2) Discuss how state and federal health privacy laws protect patients' health care information; and

3) Analyze how state and federal health privacy laws apply to different scenarios.

To facilitate student mastery of these learning objectives, students were assigned reading materials. In addition, Mohapatra recorded videos covering different aspects of the state and federal health privacy laws. She posted those video lectures, making the accompanying PowerPoint slides available to students on the module page. To assess student understanding of the reading and lectures, Mohapatra designed a multiple-choice quiz which she then put into Canvas. The quiz contained built-in explanations to accompany correct and incorrect answers so that students received direct feedback immediately after they "clicked" on their answer choice. Mohapatra also posted a discussion board problem, asking students to state their opinion on whether HIPAA and state privacy law protections were adequate, using an example of a plastic surgeon

79. Bloom's Taxonomy, IUPUI GRADUATE SCHOOL, https:/graduate.iupui.edu/doc/facultystaff/bloom.pdf [https://perma.cc/MJ5B-5WHG] (listing key verbs for learning objectives that correspond to different levels of cognitive performance).

80. See Larry Cunningham, Publishing Learning Objectives in Course Syllabi, Law SCHOOL ASSESSMENT (Aug. 18, 2016), https://lawschoolassessment.org/2016/08/18/publishing-learningobjectives-in-course-syllabi/ [https://perma.cc/UG37-8Q6R] (discussing how learning objectives help professors identify gaps between instruction and expected learning outcomes). 
who had posted on a website de-identified before-and-after photos of a breast augmentation. To make the discussions less unwieldy in her class of 75 students, she used a Canvas tool allowing her to assign students to one of several "groups." So that students were encouraged to do their own thinking, she also used a Canvas tool which prohibits students from seeing the responses of other students until they post their response. To encourage students to engage with other students, Mohapatra made commenting on at least one other student's post part of a class participation grade. Mohapatra herself participated in the discussion by either commenting individually on student responses or in a group message to the class. Finally, Mohapatra had students complete another quiz that posed HIPAA hypotheticals and required students to apply the laws they had studied to those different scenarios. She provided sample answers to which students could compare their own. These activities were all part of one module, which covered the equivalent of between two and three 90 minute in-person class sessions.

In terms of learning objectives, the recorded lectures, the quiz, and the discussion board posting aided with the students' understanding of HIPAA, which directly related to the first objective. The discussion board correlated directly to the learning objective requiring students to discuss how health privacy laws protect patients. Finally, the HIPAA hypotheticals required the students to analyze health privacy laws and apply them to different situations. In sum, Mohapatra ensured that the reading, the lectures, and the assignments all furthered mastery of the stated learning objectives.

Designing the course based on learning objectives in this manner requires much thought, time, and effort - even for a professor who has taught a course live in the classroom for many years. However, our experience suggests that following this method will produce a well-designed, high-quality course that will engage students and facilitate learning of course material and skills.

\section{B. Good Organization}

Organization is very important to an online course for a host of reasons. In online classes, students must do without the professor and the students on whom they might rely on in their live classes to remind them where the last lesson left off or what reading is due for the upcoming session. To avoid frustrating students in the asynchronous course, the professor must insure that all information needed for students to successfully complete course requirements in a timely fashion is easily and readily accessible. Students in IU McKinney focus groups, in fact, made this point specifically. They explained that with so much going on in the online course, and with so many assignments, they appreciated an organized 
course presentation and clear signals from the professor about what was expected of them and when it was expected. ${ }^{81}$

Canvas - and other learning management systems - have features that assist professors in clearly presenting course material and expectations. We use the Canvas syllabus tab to post the course syllabus and reading/assignment outline. The modules tab allows the professor to arrange modules clearly with titles and dates and to include within those modules links to any assignments. As long as the professor includes a due date in assignments created within Canvas, those due dates will be visible on the modules page. Based on experience, we suggest the professor try to make assignment due dates fall on a regular schedule. In other words, students appreciate knowing that assignments are always due on Wednesdays and Saturdays. Students are less likely to miss due dates when they are regularly scheduled, and the regular scheduling helps students plan their weeks-especially if they have more than one class with weekly assignments. Canvas has a helpful feature to assist students in keeping track of due dates, because dues dates for all assignments in the course are also populated under the syllabus tab.

Although not absolutely necessary, we also use the announcement function-especially during the first weeks of class-to remind students of upcoming assignment due dates. Although we understand that students are responsible for following the course rules, we also think that by posting those announcements, we signal that we are organized and keeping track of what students are doing-even though we are not in the classroom physically with them. In addition to helping with organization, weekly communication helps build a connection with the students that can be comparable to an in-person course.

Finally, an organized course helps to facilitate one of the advantages of an online course: namely, flexibility. For some students this means the opportunity to work slightly ahead as required by their own schedules or other commitments. We caution students not to work ahead by more than one week because lessons often build on one another, and students should have the opportunity to benefit from any group feedback posted after all students have turned in their assignments. Nevertheless, we recognize that students have different commitments outside of law school that may cause them to complete some assignments in advance to accommodate those commitments. Even if students do not want to work ahead, we open up modules two weeks in advance so that students can get more information about the upcoming weeks and a sense of the amount of work involved in upcoming assignments.

81. See Dutton et al., supra note 27 , at 526 (quoting student comments about the preference for an organized online course with expectations clearly stated). 


\section{Recorded Lectures}

Recorded lectures are the method by which we convey at least some of the material that we would have conveyed in a live class through lecture or Socratic dialogue with students. To capture and hold student attention, any one lecture should be no longer than 10-20 minutes. Instead of burdening students with a longer, uninterrupted, hour-long recorded lecture, we "chunk" lecture material into learner-controlled shorter pieces. This eases the cognitive load on students and tends to promote learning. ${ }^{82}$ Another positive is that with shorter lectures students can more easily locate any material that they may wish to review in more detail, without having to search for that material in a long lecture. For those concerned that students will not learn as much from recorded lectures as they do from live lectures in the classroom, some evidence suggests otherwise. IU McKinney students have reported that short and focused lectures enhance their learning experience. ${ }^{83}$ In the medical school context, studies have found that video lectures are equally as effective as live lectures in teaching material to medical students. ${ }^{84}$

Mohapatra's Introduction to Health Care Law and Policy class serves to illustrate our general process regarding video lectures. In a module covering Medicare (which during an in-person class would be taught over two ninetyminute class periods), Mohapatra produced four short video lectures with accompanying PowerPoints. The videos were as follows: Video 1: Introduction to Medicare (12 minutes, 36 seconds); Video 2: Medicare Part B and Part D (8 minutes, 14 seconds); Video 3: Medicare Part C (6 minutes, 14 seconds); and Video 4: Medicare Coverage, Appeals, and Payment (13 minutes, 31 seconds). Notes for one's live classes are a great starting point for developing the video scripts, but the professor has to consider which material is best covered during the lecture and which material might be better covered using quizzes or other activities, such as discussion boards. We have also learned that one can supplement lectures by the professor with other videos. For example, in that same module covering Medicare, Mohapatra required students to watch a

82. Richard E. Mayer \& Roxana Moreno, Nine Ways to Reduce Cognitive Load in Multimedia Learning, 38 EDUC. PSYCH. 43, 47 (2003); Ingrid A. E. Spanjers, et al., A Theoretical Analysis of How Segmentation of Dynamic Visualizations Optimizes Students' Learning, 22 EDUC. PsYCH. REV. 411, 413 (2010) (both discussing how segmenting reduces excess cognitive load on students).

83. See Dutton et al., supra note 27 , at 526-27 (quoting students in a focus group stating that they appreciated short focused lectures and found it hard to concentrate when lectures were long).

84. See, e.g., Thomas Brockfeld et al., Video versus live lecture courses: a comparative evaluation of lecture types and results, 23 MED. EDUC. ONLINE (2018), https://doi.org/10.1080 $/ 10872981.2018 .1555434$ [https://perma.cc/7BB5-G8HM?type=image] (finding that video and live lectures were equally effective in preparing students for the clinical part of their medical exams); Jean-Philippe Vaccani et al., The effectiveness of webcast compared to live lectures as a teaching tool in medical school, 38 MED. TEACHER 59, 59 (2016) (concluding that video lectures appear to be as effective as live lectures as a teaching tool). 
sixteen-minute video of Ronald Reagan speaking out against Medicare (16 minutes, 53 seconds).

To help ensure students can follow the lectures, we post accompanying PowerPoint slides to guide students through the topics covered in each lecture. Further, we use the functionality of Kaltura ${ }^{85}$ to add closed captions mechanically to all of our videos. This option is free and while not $100 \%$ accurate, may assist students for whom English is a second language. The feebased human-edited captions would be more accurate and appropriate should the professor need to accommodate students with hearing or other disabilities. ${ }^{86}$

Because we each had a semester or more to create our online courses, we utilized our university's faculty recording studio to tape our lectures under the guidance of a video producer ${ }^{87}$ Prior to recording, we emailed the producer notes for our script, as well as the PowerPoint slides. The producer uploaded the script notes onto a teleprompter which allowed us to deliver lectures without having to look down to refer to our notes. The producer helpfully controlled the timing of the teleprompter. The faculty taping room is also outfitted with a professional green screen which allows faculty to choose a background of their choice (we usually chose the law school). To the extent that we misstated something, mispronounced a word, or even coughed during the taping session, the video producer edited out those "mistakes," such that the video lectures have a very professional appearance.

This is but one option available for recording lectures. Many of our colleagues, in fact, record and edit their own lectures using Zoom, Kaltura, or other programs, such as Camtasia. We each sometimes tape with Kaltura. Dutton only uses it for short "feedback" videos that are more casual and conversational, which she then posts as an announcement after students have completed an assignment. Mohapatra has used both Zoom and Kaltura to record lectures, especially to update modules where there may be late-breaking case law or other developments. When recording, she finds it helpful to split her screen between Zoom or Kaltura and her notes. This allows her to read her notes while

85. KALTURA, http://corp.kaltura.com (last visited Apr. 26, 2021). Kaltura provides a SaaS, open-source video platform, popular in both the corporate and education sectors. See KALTURA: WHAT WE DO, https://corp.kaltura.com/company/about/ [https://perma.cc/8QVH-EGG3].

86. See Download and edit captions or transcripts in Kaltura, IND. UNIV., https://kb.iu.edu /d/adhr [https://perma.cc/HQJ2-X539] (providing an overview of Kaltura's closed-captioning capabilities). Closed-captioning is one of many ways that professors can accommodate students with disabilities in their online classes. See, e.g., Susan David deMaine, From Disability to Usability in Online Instruction, 106 L. LIBR. J. 531, 532, 536 (2014) (discussing both the opportunities online education can hold for students with disabilities and the challenges involved in creating appropriately designed online instruction). Accessibility in online instruction is legally required under Section 504 of the Rehabilitation Act of 1973, 29 U.S.C. $\S 794$, and Title III of the Americans with Disabilities Act, 42 U.S.C. $\S \S 12181-12189$.

87. We thank video producer, Mike Antony, for his assistance in helping us and other faculty members produce quality videos for delivery in our online courses. 
maintaining eye contact in the video. During the pandemic, Dutton has been recording her lectures remotely using Zoom with the university's professional video editor participating at a remote location. Dutton hangs a green cloth in her home office (one can also choose a virtual background), and the video producer adds in a background and the PowerPoint slides during the editing process. In short, there are many recording options available to faculty-and more will likely become available in the future, especially if online programming continues to grow and proliferate.

\section{Varied and Practice-Ready Assignments}

The ABA requires that law schools ensure that any asynchronous classes they offer to law students have interaction equivalent to that of live courses. We achieve this engagement through the video lectures, the additional posted videos, and through the many and varied assignments students must complete each week on which we provide feedback. We design assignments with our learning objectives in mind so that we and our students can assess how well they are mastering course content and skills. We have found that varying the types of assignments in courses helps to maintain student engagement. We have also found another benefit to assignments: they hold students accountable and motivate them to do the course work. Because online learning necessitates some self-discipline (since students do not have to show up at a particular time to attend class), assignments provide students with the discipline they may otherwise be lacking. ${ }^{88}$

Ideally, each module should have one or more assignments enabling the student and teacher to assess learning of the material and offering the student an opportunity to demonstrate mastery of material and/or proficiency in a skill. As noted, the learning objectives for the course and the modules will aid the professor in determining which assignments are most appropriate. Otherwise, given the many advances in technology, the professor's creativity is really the only limit to the kinds of assignments one can use in an online course. Here, we only discuss a few of the types of assignments that we use in our courses.

We both often include a weekly self-graded quiz to test concepts from the reading or lectures. These are helpful when the learning objective is to explain legal concepts. Quizzes can include various types of questions, such as multiple choice, true/false, fill-in-the blank, and even short essay. ${ }^{89}$ Some of our quizzes include hypotheticals which allow students to apply law to factual scenarios. As

88. See Ryznar \& Dutton, supra note 72, at 97 (quoting IU McKinney focus group students appreciating the fact that regular assignments kept them on task and from procrastinating).

89. See Ryznar, supra note 65 , at 450 . 
mentioned above, quizzes allow the professor to build in feedback. Students also tend to enjoy them as a method for assessing their learning. ${ }^{90}$

We also frequently use discussion questions to simulate the discussion we would otherwise have during a live classroom session. In Dutton's Online Comparative Law class, she often poses questions about a theoretical conceptsuch as whether courts in the United States should be permitted to cite to foreign law to support their decisions. Students must take a position and support it with arguments and evidence. Such discussions are useful to further learning objectives requiring students to explain, discuss, or analyze various legal concepts. In addition, Dutton uses discussion posts to help students practice their persuasive writing skills. She emphasizes the similarities between a discussion post and a short email that a lawyer might write to a client or one's supervising attorney. In those short posts, the student must state her position clearly, give the reasons why she argues as she does, and support those reasons with evidence. In response to submissions earlier in the semester, Dutton's feedback focuses on having students master the skill of clearly stating a position (she finds that initially, some students like to work up to their position and finally state it in the last sentence of their post). Later in the semester as students' ability to concisely state and support arguments improves, Dutton's individual comments become more fine-grained.

One great advantage of the asynchronous online course is that the professor can include assignments that give students a safe space to practice lawyerly skills. With practice-ready assignments, students learn to master skills that can serve them as lawyers: such as making and supporting arguments with evidence and applying law to factual situations-both in writing and orally. These assignments prepare students for an employment environment where law firms increasingly expect students to have mastered many of the lawyering skills required for the job. ${ }^{91}$ They also make students better able to actually assist real clients in the future. ${ }^{92}$ Students at our school have noted how much they appreciate the practice-ready assignments in their online courses, commenting they do not always have an opportunity to practice as many lawyerly skills in some of their live classes where Socratic-method is the main method of coursecontent delivery. ${ }^{93}$

90. See Dutton et al., supra note 27, at 527 (referencing IU McKinney students explaining the value of quizzes in their online courses).

91. See Daniel Thies, Re-thinking Legal Education in Hard Times: The Recession, Practical Legal Education, and the New Job Market, 59 J. LEGAL EDUC. 598, 605 (2010).

92. See generally Cynthia Batt, $A$ Practice Continuum: Integrating Experiential Education into the Curriculum, 7 ELON L. REV. 119, 130-32 (2015); Hannah Hayes, Recession Places Law School in the Eye of the Storm, PERSPECTIVES, Spring 2010, at 8.

93. See Dutton et al., supra note 27 , at 527-28 (referencing student comments about appreciating various practice-ready assignments). 
Dutton has created many different practice-ready assignments for her online courses. For example, in her Online Comparative Law class, she has students write several short comparative memoranda. Initially, Dutton's objective is simply to get students to follow the organizational structure she has shared for comparative analysis. After students have mastered that bigger picture concept, Dutton's feedback addresses other skills, such as ensuring that students begin paragraphs with topic sentences and fully explain the relevant parts of cases they use to illustrate points of law. In Dutton's International Criminal Law class, Dutton creates assignments to aid students in mastering advocacy skills. Dutton creates hypothetical scenarios and assigns students to the role of either prosecution or defense. She presents students with a question: for example, whether on the facts presented, the prosecution can prove the defendant committed a genocide. Dutton guides students through the process leading up to a taped oral argument. First, students must complete "analysis guides" where they list the facts "pro and con" that relate to the various elements of the crime of genocide and reach tentative conclusions about whether those elements have been satisfied. Next, students create outlines of their arguments, while also addressing and resolving counterarguments. Finally, after receiving feedback, on each of these steps, the students videotape themselves making the oral argument.

Mohapatra also uses practice-ready assignments in her courses. For example, in the online class portion of her hybrid Bioethics and the Law course (where many of the classes were online), Mohapatra required students to work in groups of between two and four people to "present" case studies to other students in the class. The students themselves created the hypothetical case studies - from the topic to the actual conflict. During the last four weeks of the course, students were assigned three case studies each week. The students who created the case studies posted their page and all related materials directly on Canvas. The remaining students in the class had to review those materials and thereafter write or post a video detailing how they would advise a hypothetical client to proceed in the situation posed. These case studies aimed to help students become more practice-ready in the field of practical bioethics. The idea was for students to use the doctrine they had learned and apply it to real world problems that were presented in the case studies. Mohapatra was pleased to find that students embraced the group work, with many using media creatively. For instance, one group included episodes of Grey's Anatomy to demonstrate a bioethical dilemma. Another video-taped themselves acting out a court scenario involving a physician who was suffering from substance use disorder and related ethical issues. Another group described a hypothetical case of a transgender patient and identification issues and included a quiz to assess student learning of the material they posted. Students in the groups were able to meet by Zoom, Google Hangout, and through Canvas breakout rooms to interact in "real time" or over email to complete these assignments. 
Dutton has experimented with group work in her asynchronous classes, but she learned that some students found arranging to work with others stressful. In particular, some students who liked to get work done early were uncomfortable working with other students who were procrastinators, especially if they did not know those students and know that they might eventually come through and do the work. Mohapatra did not encounter this issue, and students expressed enjoying the group activity described above and learning from it. That case study project constituted $20 \%$ of the students' grade in the class, and they all seemed to respond to this incentive to take the assignment seriously. Mohapatra provided a grading rubric the first week of school so students knew what to plan for in terms of picking groups and topics. To help alleviate student stress, Mohapatra also allowed students to choose their own groups. Of course, this may not work if students in the class do not already know each other.

Each professor will have to decide whether to count assignments as part of the students' class grade. We typically prefer not to grade most assignments in most of our online asynchronous classes for several reasons (although, as noted above, Mohapatra graded the case study project as it was a major ongoing project equivalent to a presentation in a live course, rather than a regular weekly assignment). First, we have weekly assignments and often many students in the class, such that grading would become onerous. To grade anything but selfgraded quizzes would require rubrics which we would share with the class. And making distinctions about whether a student should receive an $\mathrm{A}$ or $\mathrm{B}$ on one of the many weekly discussion posts in a class would not be easy-and could induce student complaints. Second, in the asynchronous course, we also envision assignments as part of the course interaction. We do not grade students on the comments they make in class, and we liken many of our online assignments to the types of activities we might do in class as part of the learning process. In short, we want students to participate without the stress of a grade.

Moreover, even when we choose not to grade assignments, we still have mechanisms to encourage students to complete assignments on time and well. ${ }^{94}$ We take pains to tell the students through announcements or in the body of the assignment itself that the assignment is for the students' benefit-to help them learn practice-ready skills. And as noted, we do create assignments that are clearly designed to help students master practice-ready skills-something that students at IU McKinney is a feature of online courses at the school that they much appreciate. ${ }^{95}$ Specifically with respect to discussion posts and written

94. Each time she has taught online, Dutton has had one or two students "complain" that they had to complete difficult assignments without being assigned a grade for doing so. But, most students have appreciated that the assignments help them assess their learning, practice relevant skills, and keep them from procrastinating. See Ryznar \& Dutton, supra note 72, at 97 (referencing anonymous student surveys in Dutton's Online Comparative Law Class).

95. See Dutton et al., supra note 27, at 527-28 (referencing student focus group comments appreciating the practice-ready assignments in their online asynchronous courses at IU McKinney). 
memos, Dutton advises students that the level of feedback they receive will be greater if there is more for her to work with in terms of the student product. Dutton also tells students if an assignment is directly related to skills they will need to demonstrate on the exam. For example, in her Comparative Law class, Dutton stresses that the short comparative memos students write during the last four weeks of class aid them not only in learning a lawyerly skill that will be valuable when they practice but will also help them with the exam: the main part of the exam requires students to write a comparative memo based on a packet of materials Dutton provides. Finally, Dutton states in her syllabus that if students fail to complete $10 \%$ of the assignments, they can be dropped from the course just as if they failed to come to $10 \%$ of the classes. ${ }^{96}$ Students are to keep track of the assignments they miss, but Dutton and Mohapatra also email them if they have missed an assignment to remind students that missing too many assignments will result in significant consequences.

With all of this said, some of our colleagues do grade assignments in their online courses. They do so because they have concluded grading is appropriate given the type of course they are teaching, the course learning objectives, and the type of assignments they require students to complete. ${ }^{97}$

\section{E. Incorporating Video Submissions}

We also incorporate video submissions into our online classes. First, we require students to introduce themselves to the professor and fellow students by video. In Mohapatra's class, each student must upload a video stating their year in law school, where they are from, why/whether they are interested in health law, and one fun fact they do not mind sharing with the class. Dutton does something similar, but she also requires students to first watch a video she and another colleague created demonstrating how and how not to properly present oneself. Our instructional video was designed to be informative and humorous, with one professor demonstrating proper presentation techniques, such as taping in front of an uncluttered background, wearing solid colors, and maintaining eye contact, while the other demonstrated the opposite.

These introductory videos help students and the professors get to know one another, and Dutton and Mohapatra make sure to comment on each video posted so that the students are assured we have watched them. Indeed, in some of the

96. The $10 \%$ rule is our law school rule for attendance. The ABA requires law schools to have policies regarding "regular attendance." ABA STANDARDS AND RULES OF PROCEDURE FOR APPROVAL OF LAW SCHOOLS 2019-2020 \$ 308(a) (AM. BAR ASS'N 2019), https://www.american bar.org/content/dam/aba/administrative/legal_education_and_admissions_to_the_bar/standards /2019-2020/2019-2020-aba-standards-chapter3.pdf [https://perma.cc/T4WT-Z69A].

97. See Celeste Hammond et al., Online Learning and Transactional Skills Courses, 18 TRANSACTIONS: TENN. J. BUS. L. 521, 530 (2016) (stating that one professor grades assignments and activities to mirror law practice in which failing to meet a deadline or respond to a client has consequences). 
videos, students give the class an even greater glimpse into their lives by introducing children or pets. In one of Dutton's classes, a student introduced his new-born child to the class! From this exercise, students gain a sense of community. They also gain technological skills and rehearse presentation and speaking skills that will serve them well when they practice as lawyers.

Some of our assignments similarly require video submissions-not only for the purpose of engaging students in the learning process, but also so that students have a chance to master important skills. For example, for discussion boards, Mohapatra sometimes encourages students to post video responses to the questions she has posed. Because students must also respond to posts by video, the discussion comes alive and feels similar to the regular back-and-forth of an in-person conversation. As noted above, Dutton has required students to tape themselves making arguments for the prosecution and defense in her International Criminal Law course. She has also had students make video presentations stating arguments in response to a discussion prompt. For example, in International Criminal Law, Dutton required students to post a video submission setting out their recommendations and analysis regarding the best method for addressing a post-conflict situation.

The reality is that professionals are increasingly called upon to conduct business over video-link, and these assignments help students prepare to present themselves well in that environment. Even before the pandemic, courts were conducting hearings remotely. ${ }^{98}$ Law firms were similarly meeting with clients or co-counsel over video-link to conduct some of their business. ${ }^{99}$ When the pandemic hit, courts and other businesses began operating remotely, ${ }^{100}$ with

98. Courts have been using video conferencing for decades. See, e.g., Kelli L. Larson, Federal Courts Video Conferencing Expected to Save Time and Money, MONT. LAW., Mar. 1998, at 31, 31; Court Briefs, Haw. BaR J., Apr. 2013, at 25, 26; Tawnya Plumb, Video Conferencing: Changing the Way Courts Do Business, WYO. LAW., Aug. 2011, at 56, 56.

99. See Jonathan Walfisz, How to Effectively Make an Entire Law Firm Work Remotely, LEXOLOGY (Mar. 31, 2020), https://www.lexology.com/library/detail.aspx?g=f1411222-76ba-4e e8-bfdb-70a36c45b839 [https://perma.cc/E2ZY-EZBJ] (discussing upsides of law firms that were remote-only prior to the COVID-19 pandemic and speculating that this may become more common).

100. People with disabilities have noted that workplaces sometimes set forth obstacles for them to work from home, but when able-bodied individuals needed such accommodation due to the coronavirus, entire workplaces shifted to this model in a few days. Andrew Pulrang, 3 Ways The COVID-19 Pandemic Could Change Disability Policies and Practices, ForBES (Apr. 20, 2020, 1:35 PM), https://www.forbes.com/sites/andrewpulrang/2020/04/20/3-ways-the-covid-19-pandem ic-could-change-disability-policies-and-practices/ [https://perma.cc/VGK2-357N] (“[I]t's hard not to feel taken aback at how quickly and enthusiastically the 'work from home' lifestyle has been accepted, almost as a fun novelty. For decades, disabled people have lost major opportunities because of what now turns out to have been indifference, or simple human reluctance to try doing things differently."). 
contact between individuals occurring frequently over video or audio-link. ${ }^{101}$ In 2020 , some companies said they would continue to allow their employees who could do so to work remotely through the rest of the year, and it appears likely that a hybrid work model will prevail. ${ }^{102}$ Others, like Twitter, have stated that they plan to continue to allow employees to work from home "forever." 103 Based on this forced experiment, many employers have realized that employees can

101. See, e.g., Todd A. Curry et al., Unlike the Supreme Court, State Courts Have Responded Quickly to the Pandemic. Here's Why., WASH. PosT (May 12, 2020, 6:00 AM), https://www.wash ingtonpost.com/politics/2020/05/11/unlike-supreme-court-state-courts-have-responded-quicklypandemic-heres-why/ [https://perma.cc/LU2V-RQQ8] (offering examples of state courts using technology to do remote hearings); State Courts Getting Creative During the Coronavirus Pandemic, NAT'L CTR. FOR STATE COURTS (Apr. 10, 2020), https://www.ncsc.org/Newsroom /Public-health-emergency/Newsletters/Courts-get-creative.aspx [https://perma.cc/SEM5-R3R5] (discussing judges holding court in parking lots and RVs). Also, for the first time, the Supreme Court held oral arguments by audio-link. See Nina Totenberg, Supreme Court Arguments Resume - But With A Twist, NPR (May 4, 2020, 5:01 AM), https://www.npr.org/2020/05/04 /847785015/supreme-court-arguments-resume-but-with-a-twist/ [https://perma.cc/E73P-HMHG]; Editorial, High Court Makes History in Response to Coronavirus, BOS. GLOBE (May 7, 2020, 12:07 PM), https://www.bostonglobe.com/2020/05/07/opinion/high-court-makes-history-response-coro navirus/ [https://perma.cc/6VE3-JPMB] (discussing the U.S. Supreme Court's decision to hear oral arguments via telephone and allow them to be broadcast live and noting that nine of the 13 courts of appeals were already doing so as well).

102. See Salvador Rodriguez, Facebook Will Allow Most Employees to Work from Home Through the End of 2020, CNBC (May 7, 2020, 7:02 PM), https://www.cnbc.com/2020/05/07/face book-to-allow-most-employees-to-work-from-home-through-end-of-2020.html [https://perma.cc 18Y5P-6BL3]; PwC, It's Time to Reimagine How and Where Work Will Get Done: PwC's US Remote Work Survey (Jan. 12, 2021), https://www.pwc.com/us/en/library/covid-19/us-remotework-survey.html [https://perma.cc/TY3X-3M2E] (discussing the results of a 2020 survey of 133 executives and 1,200 office workers which suggested that hybrid workplaces are likely to become the norm); GENSLER RESEARCH INSTITUTE, US Workplace Survey 2020: Summer/Fall, https://www.gensler.com/gri/us-workplace-survey-2020-summer-fall [https://perma.cc/GXV8-R6 UX] (discussing the results of a survey of more than 2,300 U.S. workers in which over half preferred a hybrid work model).

103. See Catherine Thorbecke, Twitter Says it Will Allow Employees To Work from Home 'Forever', ABC NEws (May 12, 2020, 2:37 PM), https://abcnews.go.com/Business/twitter-employ ees-work-home-forever/story?id=70641702 [https://perma.cc/K9ME-MJCW] (stating that if employees wished to work from home in the future, they could choose to do so); see also Catherine Thorbecke, What Offices May Look Like in a Post-Pandemic Era, if They Exist at All, ABC News (May 8, 2020, 4:00 AM), https://abcnews.go.com/Business/offices-post-pandemic-era-exist/story ?id=70512282 [https://perma.cc/E373-7HLJ] (stating that Microsoft and Zillow have suggested they will be extending their remote work policies in the future based on their learning from this "experiment"); Matthew Finnegan, Remote Working, Now and Forevermore?, COMPUTERWORLD (Apr. 13, 2020, 3:00 AM), https://www.computerworld.com/article/3536083/remote-working-now -and-forevermore.html [https://perma.cc/AC2N-PFW4] (noting that some companies are now letting people work remotely indefinitely and speculating that remote work will become much more common). 
work productively from home and that they can save on costly office space. ${ }^{104}$ As a side benefit, with more remote working, we all get cleaner air. ${ }^{105}$

In short, technology-assisted remote work is only likely to increase in the future. Online classes and communicating with professors and students online, via live and videotaped interaction, can help train our students and future lawyers for the workplace of the future.

\section{F. Feedback}

Students enjoy feedback and want to know how they are doing in a class. ${ }^{106}$ This is particularly important in the online environment to help students feel engaged and connected to the professor. ${ }^{107}$ We review all assignments so that we can assess whether students are mastering course material. If we find general confusion regarding some topic, we will send an announcement to all students explaining the topic in more detail in writing or by a mini-lecture we tape ourselves. We may also include additional reading or other material to further students' understanding with that announcement. This opportunity to regularly review student work highlights a benefit of asynchronous online courses: professors can see where students are having difficulty if they have crafted assignments matched to the lesson's learning objectives.

We also give individualized feedback on as many assignments as possibleeven quizzes that grade themselves-so that students know that we are watching their progress and so that we can acknowledge those who are doing well or provide some warning to those who may be doing less well. This does not need

104. See, e.g., Adedayo Akala, More Big Employers Are Talking about Permanent Work-fromHome Positions, CNBC (May 1, 2020, 9:02 AM), https://www.cnbc.com/2020/05/01/major-compa nies-talking-about-permanent-work-from-home-positions.html [https://perma.cc/EJ32-X64G] (quoting company leaders as saying they will likely need less costly real estate in the future as they allow more employees to work from home).

105. See, e.g., Beth Gardiner, Pollution made COVID-19 worse. Now, lockdowns are clearing the air, NAT'L GEOGRAPHIC (Apr. 8, 2020), https://www.nationalgeographic.com/science/2020/04 /pollution-made-the-pandemic-worse-but-lockdowns-clean-the-sky/ [https:/perma.cc/T7MG-4B M6] (covering environmental impact of coronavirus lockdowns); Skye Schooley, Remote Work Trends and the Coronavirus: What Changes Are Coming?, BUSINESS.COM (Apr. 23, 2020), https://www.business.com/articles/remote-work-trends-after-the-coronavirus/ [https://perma.cc/Y 6J9-U9EU] (discussing many different benefits-in addition to environmental-of working remotely).

106. See, e.g., Nancyruth Leibold \& Laura Marie Schwarz, The Art of Giving Online Feedback, $15 \mathrm{~J}$. EFFECTIVE TEACHING 34, 34, 37, 42 (2015) (setting forth best practices for feedback in the online environment); Susan Shedd Conrad \& Nada Dabbagh, Student and Instructors Perceptions of Helpful Feedback for Asynchronous Online Learning: What Students Want from Instructor Feedback, in INNOVATIVE APPLICATIONS OF ONLINE PEDAGOGY AND COURSE DESIGN 177, 177 (Ramesh C. Sharma ed., 2018) (discussing student perceptions of different types of feedback in online courses).

107. See Ryznar \& Dutton, supra note 72, at 101-02 (discussing student comments noting how consistent feedback helped them feel engaged in their online classes at IU McKinney). 
to take a lot of time. For example, both of us will comment "great job" if a student has gotten $100 \%$ of the answers correct on a quiz. ${ }^{108}$ For students who have answered some questions incorrectly, we might direct the student back to the reading or a lecture. We provide individual feedback on other assignments as well, including papers and discussion posts. These comments can take more time, of course. But, students benefit from both substantive comments and from comments that are more structural in nature - such as those that point out to a student that they need to begin a new paragraph with a topic sentence stating the idea of that paragraph. As mentioned above, students have commented how much they appreciate this feedback, and have noted that such feedback is not ordinarily available in the law school context where many classes rely on a final exam or a final exam and a mid-term to assess student learning of material. ${ }^{109}$

\section{CONCLUSION}

We hope this Article gives some measure of assurance and confidence to professors who may be preparing to teach an online law school course for the first time. As doctrinal law professors who have taught primarily in the classroom, we empathize with the unease or stress associated with delving into the uncharted territory of asynchronous online course creation. We overcame that unease and stress, and others can as well. And we have found that our online courses can deliver an engaging learning experience that enables students to master course content and practice and perfect lawyerly skills while doing so. The emergency transition to Zoom education in March and April 2020 was a stop-gap measure, and the teaching delivered during that period may not represent the best of online education. To the extent that law schools are going to offer some amount of online programming in response to COVID-19 and its continued threat, we encourage them to consider moving beyond emergency remote teaching. With a few months of planning, law professors can design a high-quality online course for delivery to students, especially with the support of their administration and institution.

108. Many IU McKinney students have expressed a preference for quizzes as an assessment tool in their online classes and also stated that they like the instant feedback that the quiz itself generates as they answer the questions posed. See, e.g., id. at 102 (referencing the automatic feedback from quizzes).

109. See Dutton et al., supra note 27 , at 528 (referencing student comments appreciating the availability of feedback in online law classes). 